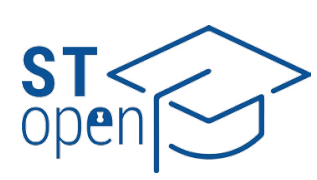

(c) 2021 The Author(s)

ST-OPEN @ 202

\title{
Installation of stainless metal reinforcements in stone cultural monuments
}

\author{
Jure Balić, Siniša \\ Bizjak
}

Conservation and Restoration Department, Arts Academy, University of Split, Split, Croatia
Correspondence to:

Siniša Bizjak

University of Split, Arts Academy, Zagrebačka

3 , Split, Croatia

bizjaksinisa@gmail.com

Cite as:

Balić J, Bizjak S. Installation of stainless metal reinforcements in stone cultural monuments. ST-OPEN. 2021; 2: e2021.1918.1.

\section{DOl:}

https://doi.org/10.48188/so.2.2
Objective: To provide examples of the installation of stainless-steel reinforcements in a stone cultural monument as part of conservation and restoration work.

Methods: During conservation and restoration works, metal elements in stone monuments are replaced by stainless steel, which shares the same physical properties as, for example, iron, but its chemical properties are much superior. Estimates of appropriate reinforcement, technical drawings and a detailed plan are drafted before the installation of stainless-steel reinforcements in the stonework itself. For more demanding calculations and designs, structural and other engineers and architects were consulted to obtain the optimal dimensions of structural elements.

Results: The presented examples of stone monuments (an ancient stone sarcophagus, two ancient sculptures, one medieval portal, two baroque baptismal fonts and a baroque bell gable) were reinforced with stainless steel. A reinforcing mesh was utilized to connect fragments of the sarcophagus and reconstruct the missing parts. The sculptures were found in fragments and required steel reinforcement to be set up in a free-standing position. The baptismal fonts were also found in fragments due to the corrosion of their iron clamps; they were furnished with a detachable, externally invisible steel reinforcement. The medieval portal was at risk of collapse due to the static instability caused by the rupture of its load-bearing lintel. The lintel was reinforced with a steel bar, which absorbs compression forces acting on the stone superstructure. The baroque bell gable was a prime example of a monument damaged by its iron clamps. These were completely removed and the structural stability was secured by embedding a reversible steel structure in the stonework.

Conclusion: Good physical and chemical properties make stainless steel the basic material in the reinforcement of stone cultural monuments. Its application in the conservation and restoration of stone monuments is currently the best and most efficient solution for restoring sustainable structural stability, original appearance and optimal positioning of monuments, as well as preventing further deterioration. 


\section{Introduction}

Various metals have been utilized in stonework since ancient times. As a building material, stone alone could not fulfil human aspirations to build larger and more massive buildings. Therefore, metals were introduced and combined with stone as a basic building material to additionally improve the sustainability of stonework. Initially, metals (iron, bronze, and lead) were utilized to join two stone blocks in walls and masonry. Iron or bronze clamps were wedged into carved sockets to connect two adjacent stone blocks and then sealed with molten lead (Adam, 2005). This method of joining helped secure the blocks, prevent them from shifting and strengthen the entire stone structure. However, due to its poor corrosion resistance, iron in stonework is today considered to be one of the main causes of deterioration of stone monuments (Barišić, 2010). It is, therefore, replaced with stainless steel, which has a strength comparable to iron (this depends on the composition; some stainless-steel alloys have an even higher strength), but better corrosion resistance, good machinability and weldability, as well as a higher coefficient of thermal expansion (Awasthi, Gautam \& Dheer, 2005). Depending on the shape and condition of the monument, the metalwork needs to be logically and appropriately designed and constructed. Stainless steel reinforcement in the form of bars, dowels or more demanding metal structures is utilized when a stone monument is in poor condition, fragmented or missing a fragment, as well as in the cases of jeopardized stability and decayed material (Lee, 2008). Although we have used stainless steel to reinforce a great number of stone monuments, in this paper we will present only those works that required innovative design and execution solutions.

\section{Methods}

The purpose of installing stainless-steel construction is: a) to transfer destructive forces from the stone monument to the embedded metalwork, thus preventing further deterioration and loss of stonework, b) to restore the monument's structural integrity, c) to connect two or more fragments, and d) to provide a skeleton when reconstructing missing pieces.

\section{Calculation of metalwork}

There are several considerations to take into account when calculating and designing metalwork: a) it can safely withstand the load of the stone monument and buffer all destructive forces acting on the stone monument, b) in the future, the metalwork itself will not have a destructive effect on the monument, c) it is, preferably, reversible, and d) it does not deface the appearance of the stone cultural monument.

\section{Embedding stainless-steel in a monument}

If possible, the embedding should be reversible; detachable metalwork is used to this end (Crnković \& Šarić, 2003). Detachable structural reinforcement for stone monuments may be divided into two types. The first involves turning a steel rod so its diameter is narrower than the bronze metal cup into which it is to be inserted (Figure 1). The reason for opt- 


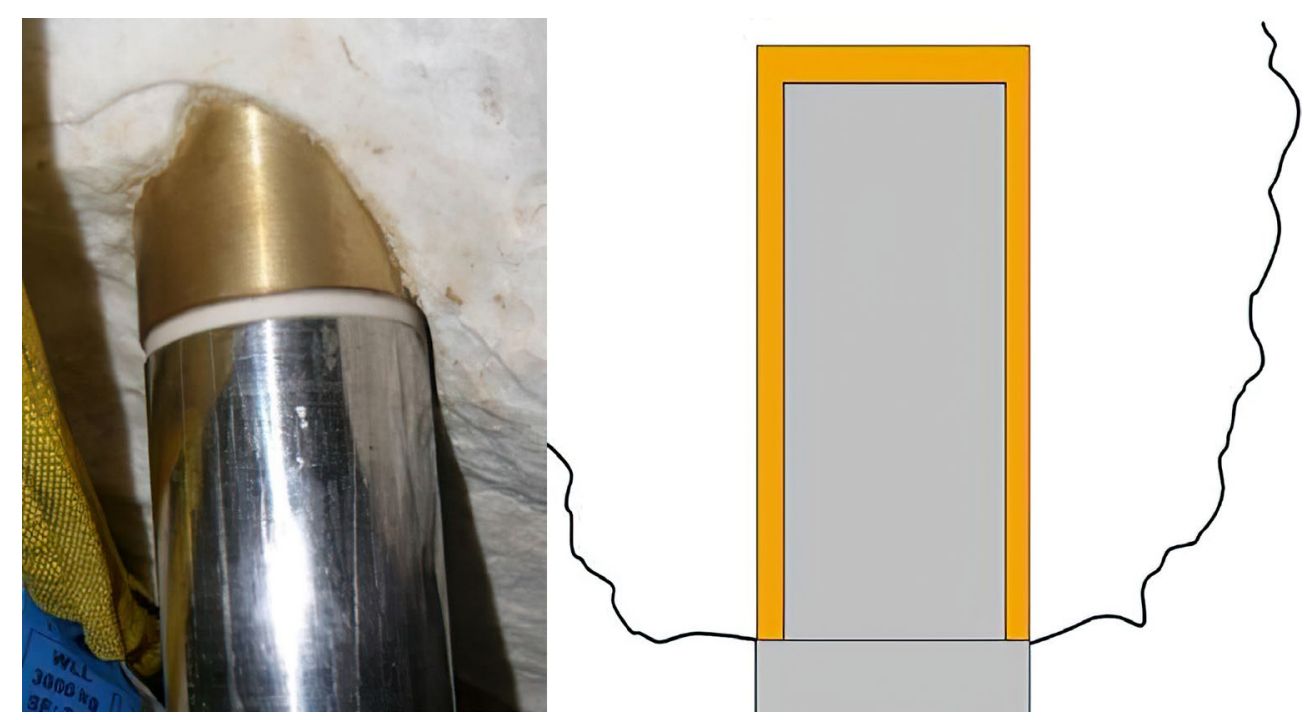

Figure 1. A rod embedded in a bronze cup; the cross-section of the bronze cup is shown in yellow, and the stainless-steel member embedded in the cup is grey. The white ring in the left photo is just a plastic distancer placed due to the fine hight adjustment of the sculpture. Later it was removed (photo and drawing by Siniša Bizjak, 2016).

ing for different materials is their different hardness, which prevents wedging between metals (Čorić, 2017), because identical metals can easily get jammed between each other when mounting or dismantling the parts of the monument. We must keep in mind that it is generally always advisable to use only one type of metal and not combinations of two or more metals. The reason for this is what is called contact corrosion, which rests on the different corrosion potentials of the various metals (Zhang, 2011). Two different metals become electrodes in a liquid medium, such as water with salts dissolved in it. However, we use this combination of metals only in highly controlled climatic ambientes such as museum interiors.

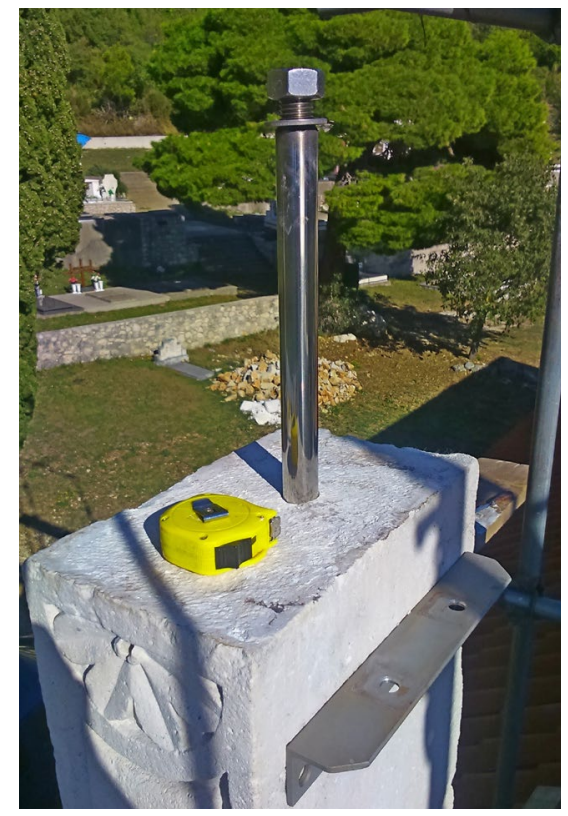

Figure 2. An embedded threaded rod with a tightening nut (photo by Duje Ordulj, 2016, reproduced with permission).

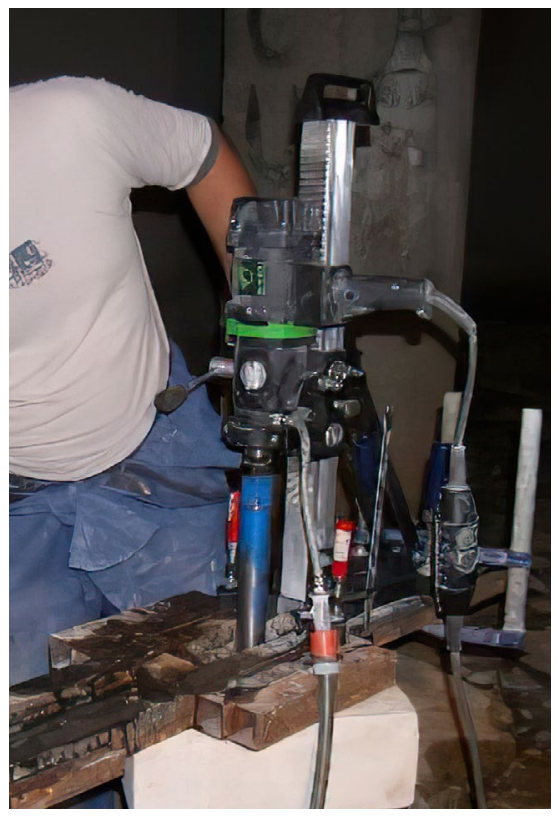

Figure 3. Drilling a hole in a stone monument with an anti-vibration drill (photo by Ivo Donelli, 2006, reproduced with permission). 
The second type uses rods with turned threads and tightening nuts. The advantage of this solution is that, unlike the first type, it can be arranged both vertically or horizontally and remain equally easy to disassemble. We use these structures to connect cracked fragments by the controlled tightening of nuts to buffer compression and tensile forces that may have a destructive effect on the stone cultural monument (Figure 2).

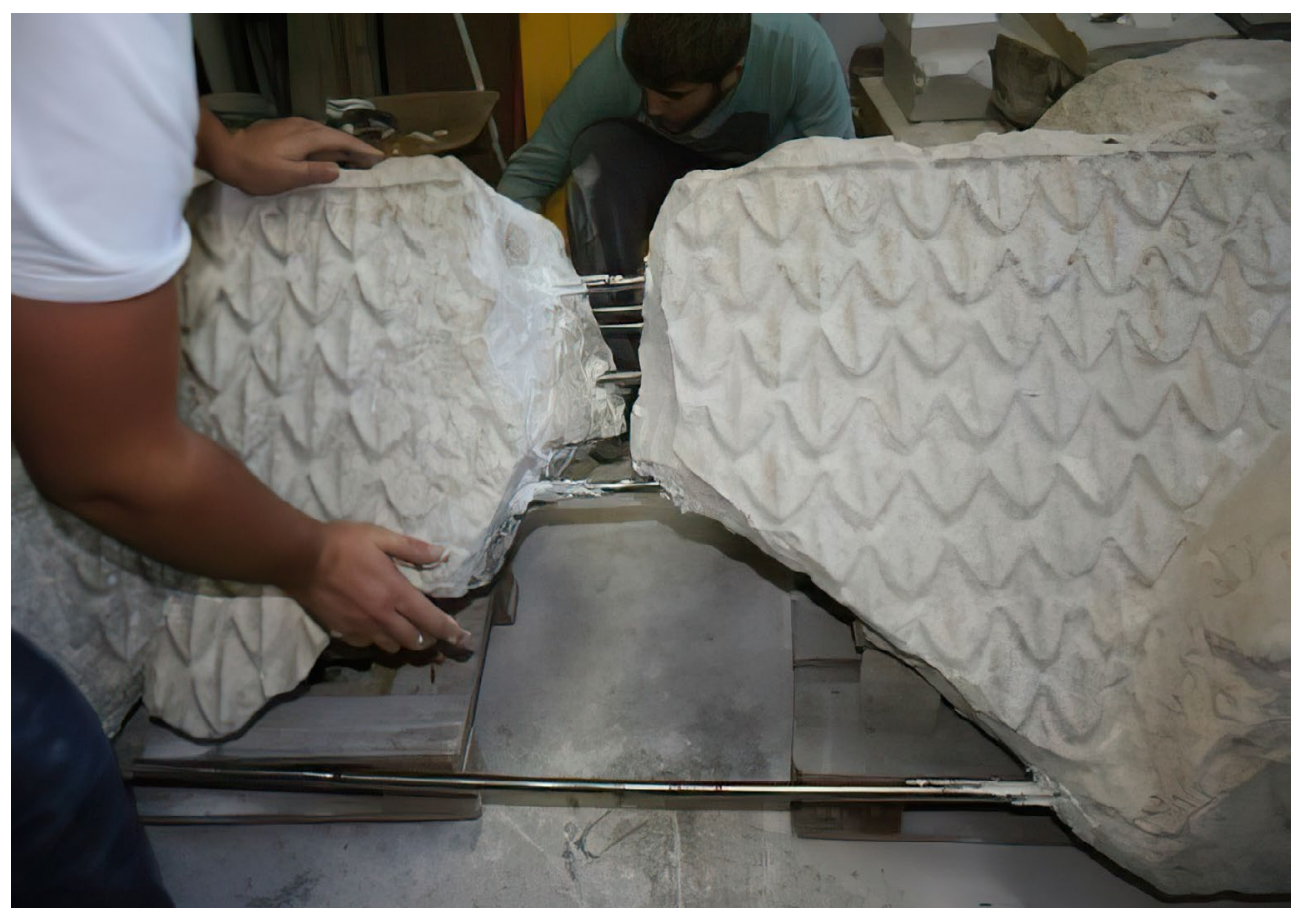

Figure 4. Stainless steel members are glued to the stone to join fragments with no shared point of contact (photo by Siniša Bizjak, 2019).

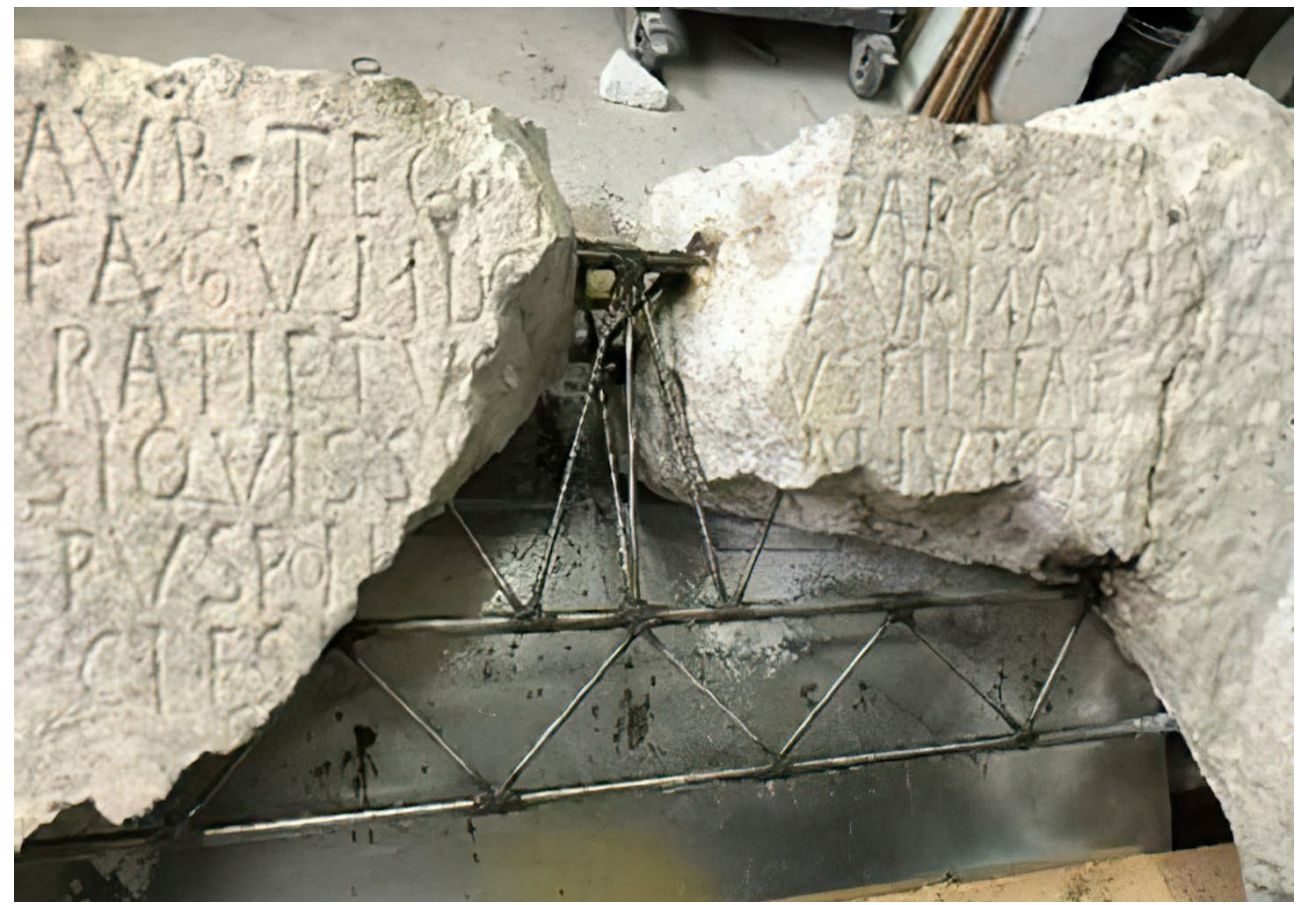

Figure 5. An example of a welded load-bearing stainless steel metal grid (photo by Siniša Bizjak, 2019). 
After precisely gauging the integration of the construction zones, machine drills are used to drill holes in the stone. A drilling method is selected based on the state of the stone monument and the size of the structure. For example, hammer drills with SDS bits or anti-vibration drills with water-cooled bits may be used (Figure 3). Cooling is used when drilling deeper holes or working with monuments in poor condition, as these may sustain damage due to vibrations from hammer drills. After removing stone dust from the holes, the prepared stainless-steel reinforcements are glued to the stone (Figure 4). Two-component epoxy adhesives are most commonly used. Sometimes, structural elements cannot be prearranged into their desired position and need to be welded together on the spot (Figure 5). It is important to note that in certain cases, the stainless- steel should not be glued to the stone due to its physical property - thermal expansion. This is especially important when dealing with outdoor monuments, which may crack due to heating and varying thermal expansion coefficients of applied materials (Donelli \& Malinar, 2015).

\section{Results}

Six interventions on stone monuments and their results are described below.

\section{Ancient marble sculpture of Emperor Augustus from the Narona Archaeological Museum, 2016 - 2017}

The installation of metalwork in the ancient sculpture of Emperor Augustus from the Narona Archaeological Museum (Marinković, 2014), resembled the intervention on the marble sculpture of Venus Pudica described later in the text. A detachable structure consisting of a bronze cup and stainless-steel bar was embedded in the marblework. The bar follows the anatomy of the statue's leg and attaches to a stainless-steel metal base that keeps the sculpture upright (Figure 6). As the load-bearing bar was visually distracting, we opted for reconstructing the missing pieces to cover the metal structure. After moulding

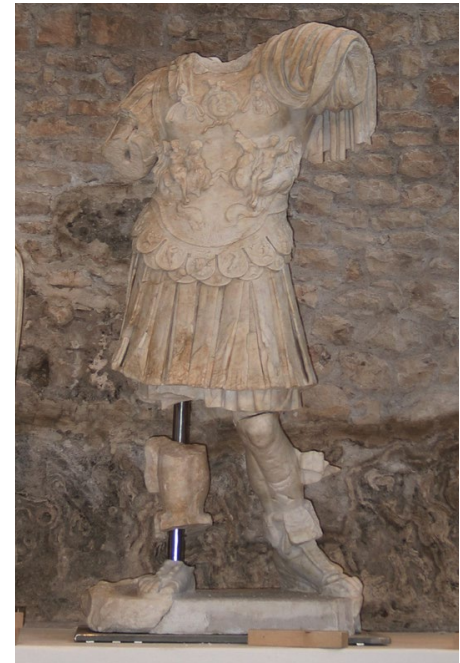

Figure 6. The ancient sculpture of Emperor Augustus with visible load-bearing reinforcement of the right leg (photo by Siniša Bizjak, 2016).

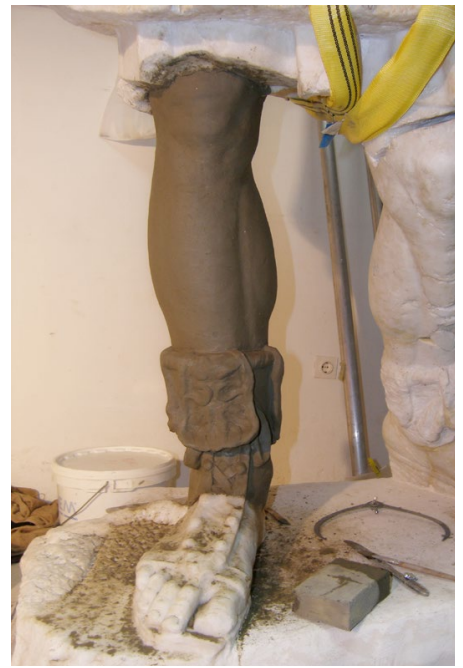

Figure 7. Moulding the missing portions of the right leg of the Emperor Augustus sculpture to facilitate the visualization of the sculpture's integrity (photo by Ivo Donelli, 2016, reproduced with permission).

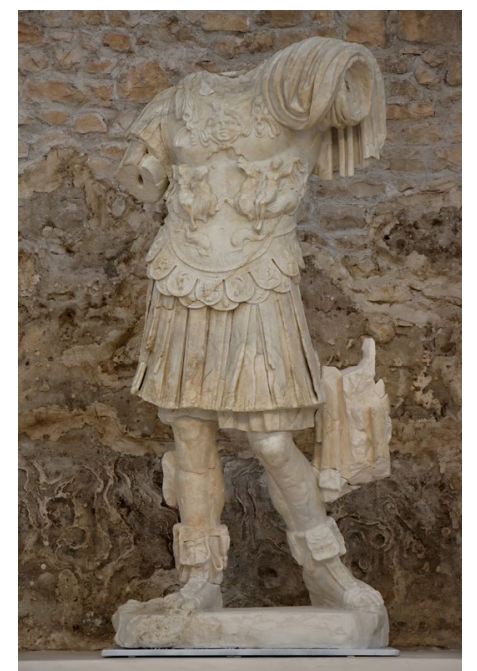

Figure 8. The sculpture of Emperor Augustus after the intervention, with adapted parts of the right leg, reconstructed using artificial marble to hide the load-bearing steel reinforcement (photo by Siniša Bizjak, 2017). 
and casting, artificial marble casts were installed in the sculpture and then retouched and patinated to fit into the whole (Figure 7, Figure 8). Note that this structure is modifiable and can be completely removed.

\section{Ancient marble "Venus Pudica" sculpture from the Skupi site in Northern Macedonia, $2010-2011$}

"Venus Pudica", a marble sculpture of the Roman goddess of love, was discovered at the Skupi site near the city of Skopje in Macedonia, in 2008 (Ončevska Todorovska, 2011). The sculpture, made from white Greek marble, was found in 16 fragments, with parts of the legs and feet missing (Figure 9). After running analyses of the type of marble and harmful water-soluble salts, the joints between the fragments were cleaned. After the cleaning, drilling points were defined for the installation of stainless-steel dowels. Once the fragments were joined, a stainless-steel metal structure needed to be designed to hold the sculpture in the optimal vertical position, in the contrapposto pose. Drilling was done with an anti-vibration drill with a $32 \mathrm{~mm}$ bit. The method of embedding a detachable metal reinforcement was chosen in this case as well. Firstly, turned bronze cups were inserted into drilled holes to hold the bars, which in turn follow the anatomy of the leg and foot and keep the sculpture in the optimal position. Initially, the bars that carry the entire sculpture and follow the position and anatomy of the legs were made of wood and appropriately positioned. Based on the wooden model, a stainless-steel reinforcement with a base was produced to stabilize the whole sculpture (Figure 10). Missing parts were reconstructed over the metalwork using artificial marble to completely conceal the steel reinforcement (Figure 11). It is important to note that this structure is completely detachable and can be adjusted or completely removed if the original fragments of the legs are ever discovered.

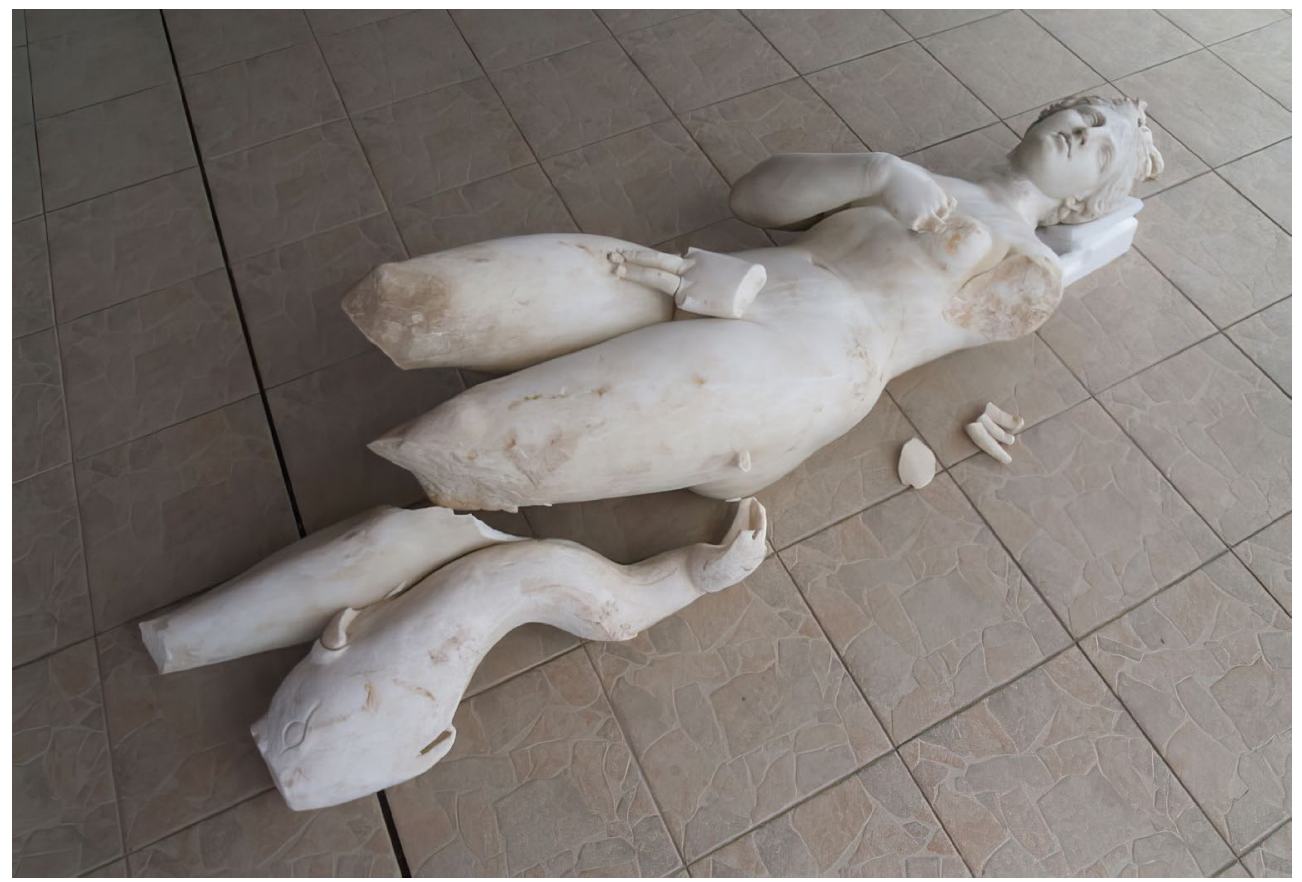

Figure 9. The state of the sculpture after archaeological research. It was discovered in 16 fragments. Pieces of the right shank and left foot with the base are clearly missing (photo by Marina Ončevska Todorovska, 2010, reproduced with permission). 


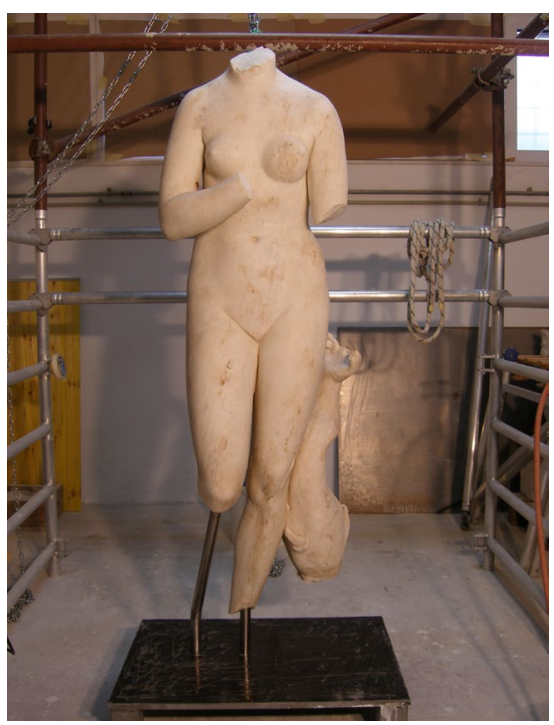

Figure 10. The stainless-steel metal reinforcement ensures the stability of the sculpture missing parts of the legs conceal the load (photo by Siniša Bizjak, 2011).

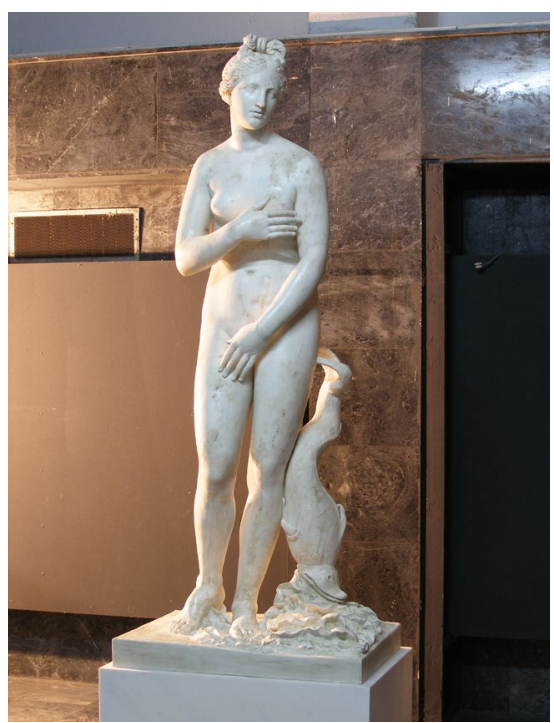

Figure 11. The sculpture after installation at the Skopje City Museum. Reconstructed bearing metal structure (photo by Siniša Bizjak, 2011).

\section{Two baroque baptismal fonts from the Church of St. Euphemia in Rovinj, 2003}

Two baroque marble baptismal fonts from the church of St. Euphemia in Rovinj (Marković, 1996), experienced significant structural disintegration due to the corrosion of iron members and their expansion into the marble structure (Figure 12). The baptismal fonts were initially in a very poor condition, held in one piece by copper and iron clamps and steel hoops installed preventively in an attempt to secure them. During the conservation and restoration works, many of the marble fragments were glued back, but the integrity of the monument was severely impaired. As the base and column could no longer bear the enormous weight of the basin, an innovative stainless-steel member was embedded in the stonework to fully absorb the compression forces from the monument and transfer them to the foundation (Figure 13 and Figure 14). When dimensioning the steel column, we started from the assumption that the baptismal font was loaded with a $500 \mathrm{~N}$ force (roughly corresponding to $50 \mathrm{~kg}$ of vertically suspended mass). This assumption was based on the fact that children would often grab and swing off the edge of baptismal fonts during the Eucharist. A vertical force of $500 \mathrm{~N}$, acting on the edge of the basin (520 $\mathrm{mm}$ radius) causes a $260 \mathrm{Nm}$ moment. It is assumed that the moment is transferred to the column via contact forces occurring at the upper and lower edge of the hole in the basin. These forces cause a couple equivalent to a $260 \mathrm{Nm}$ moment and amount to $866.67 \mathrm{~N}$ (Krstulović Opara, 2003). This force couple is received by the base, which was originally a stone block at the foundation of the monument. This concept, based on just one hole in the ground with a diameter of about $50 \mathrm{~mm}$, is the most favourable, given the possibility of cracks in the stone floor and breakage of the floor itself. The steel column, therefore, needs to meet the strength requirement of over 17.44 MPa, which is true of every steel alloy. In places where one stone member stacks onto the other, lime mortar was used as a kind of cushion between the two stone members. The same structure was utilized for both baptismal fonts. The advantage of this structure is that it allows for the disassembling of the monument into its constituent elements at any time (Figure 15). 


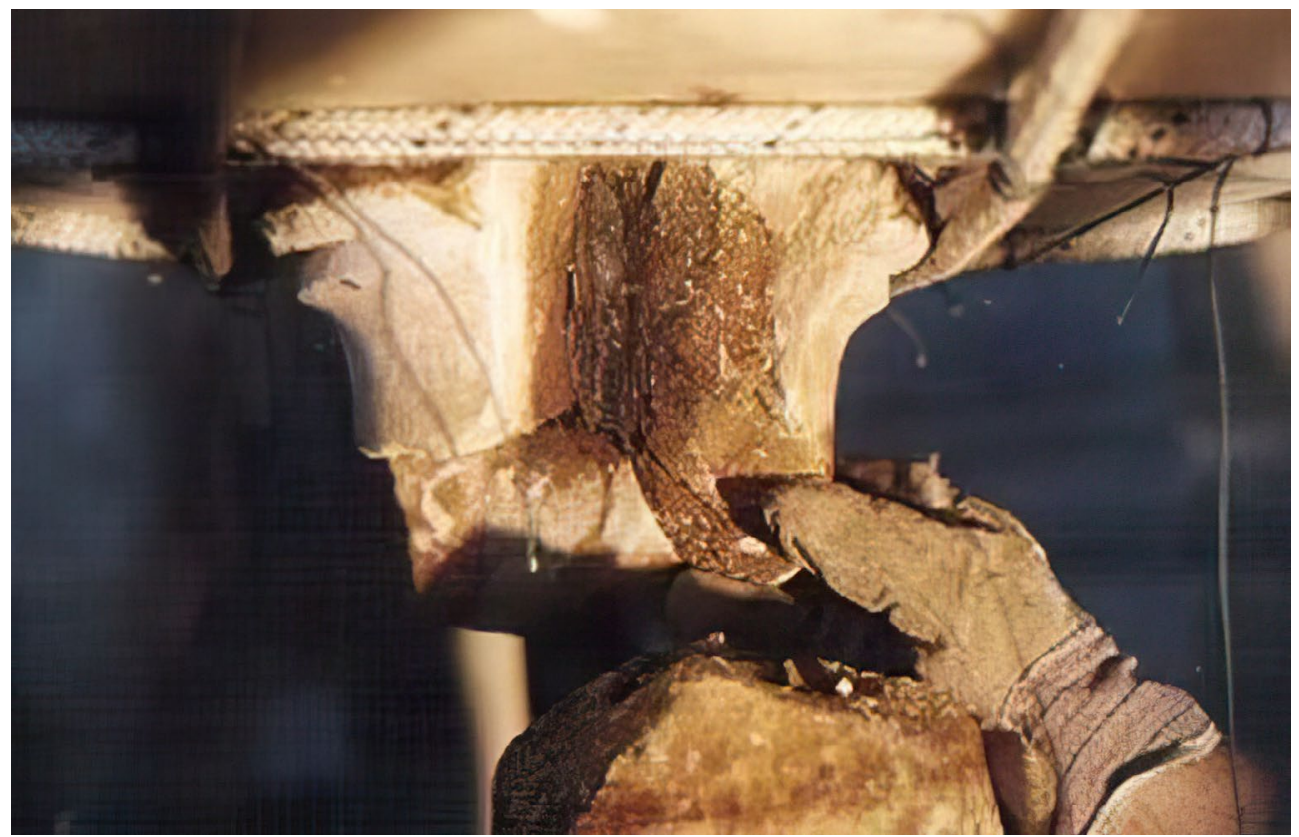

Figure 12. Cracked marble of the St. Euphemia baptismal font caused by the corrosion of an iron dowel (photo by Siniša Bizjak, 2003).

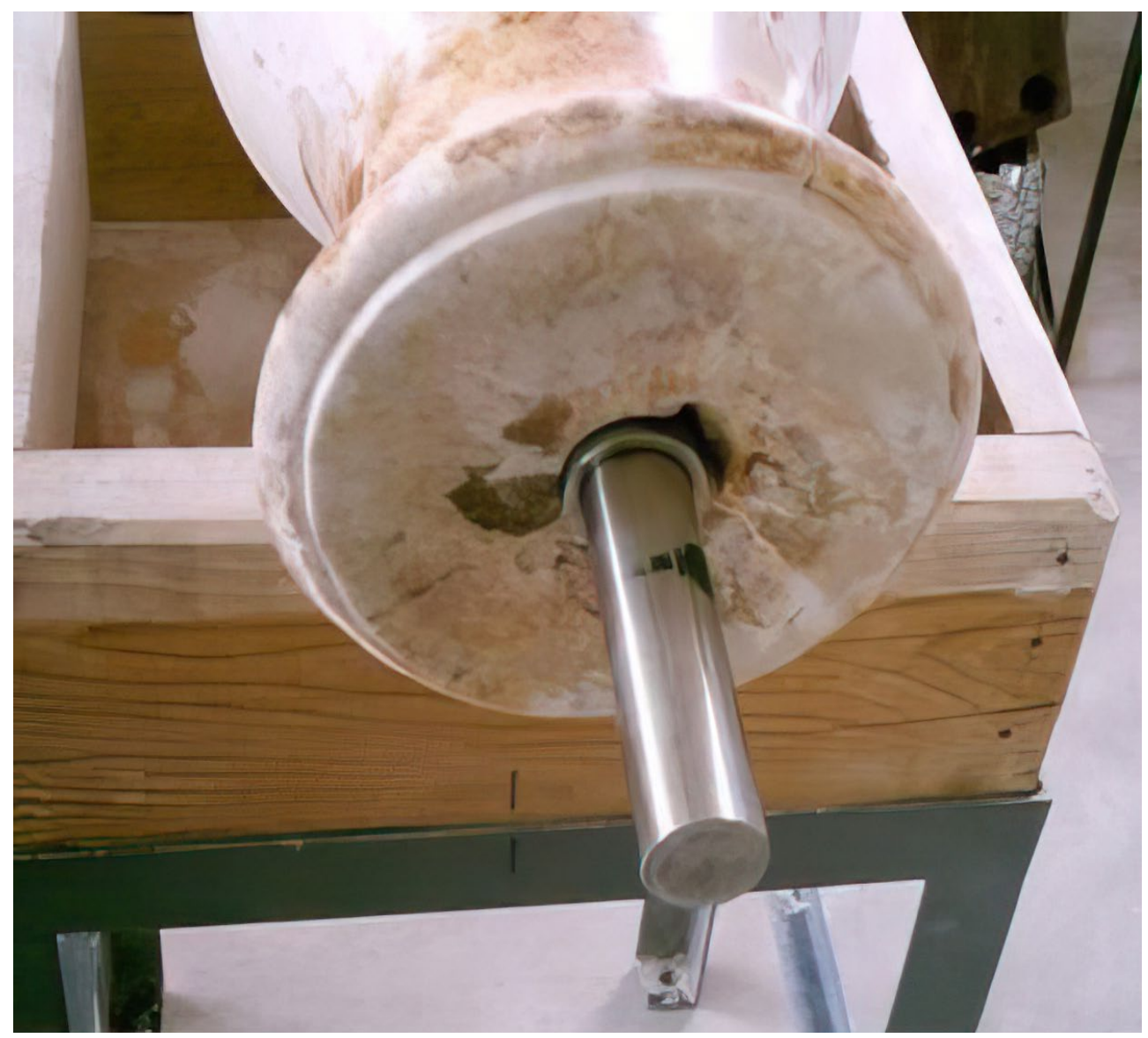

Figure 13. A detail of the installed internal structure. Part of the detachable internal structure is visible inside the marblework of the baptismal font. The same model was applied to both monuments (photo by Siniša Bizjak, 2003). 


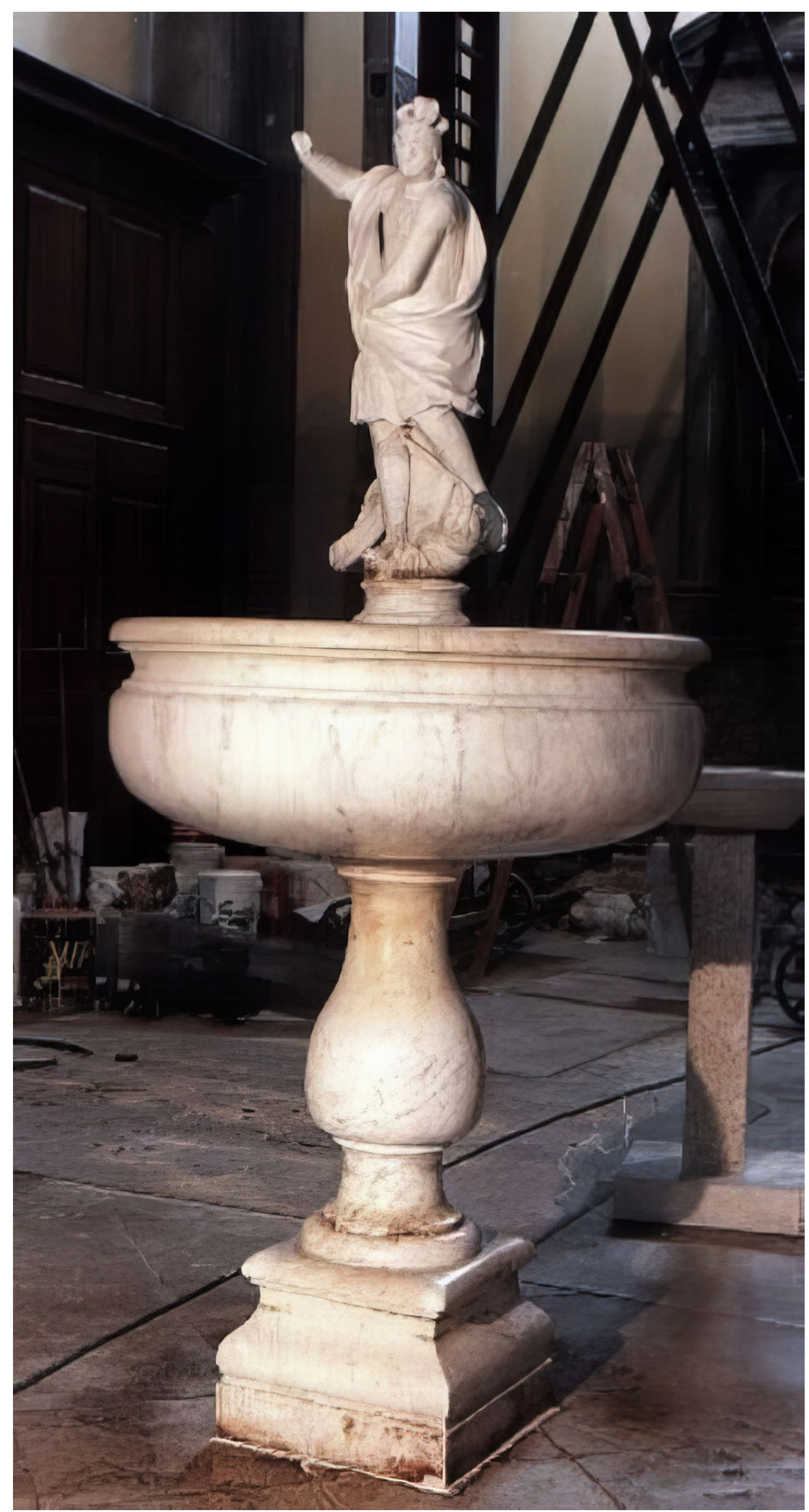

Figure 14. The St. George baroque baptismal font after the installation of "invisible" reinforcement (photo by Siniša Bizjak, 2003).

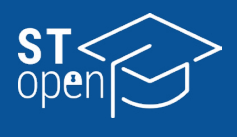




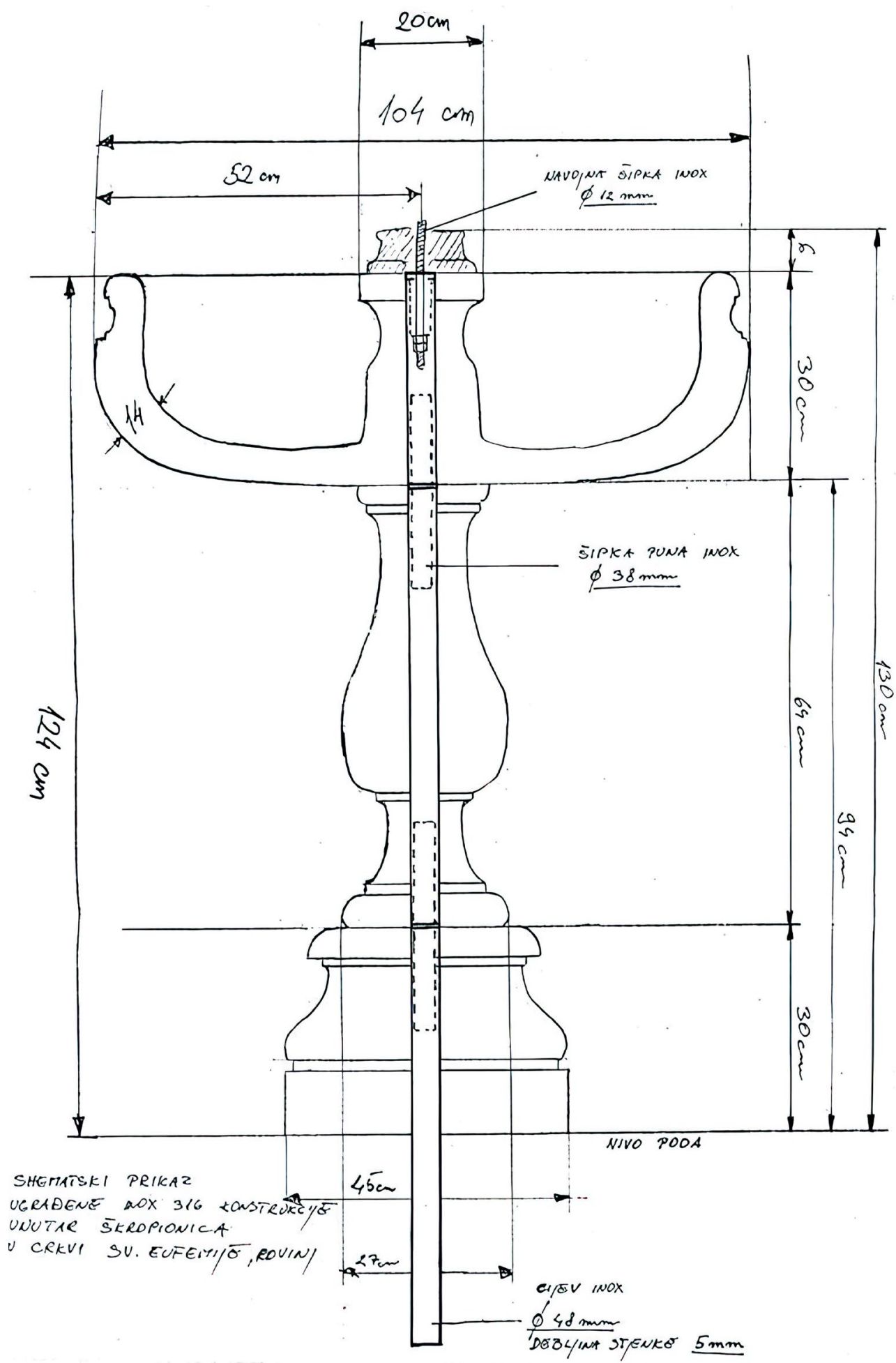

Figure 15. The cross-section of the baptismal font showing the detachable internal stainless-steel structure (drawing by Siniša Bizjak, 2003).

\section{Stone sarcophagus of Quintia, wife of Flavius Valens, Salona, 2017}

The sarcophagus of Quintia is located at the Manastirine archaeological site in Solin (Bulić, 1904; Matijević, 2019). The sarcophagus was in a very poor condition and the loss of its original structural elements was visible at a glance (Figure 16). The sarcophagus was full of earth and stones, overgrown with vegetation and covered in dark crusts, lichen and other deposits. Several missing fragments were discovered while clearing the earth out of the sarcophagus. These were cleaned and transferred to the workshop with the rest 
of the sarcophagus. After consolidating, gluing, and bonding the collected fragments of the sarcophagus, the installation of stainless-steel metalwork began. 24 holes were drilled into the sides of the sarcophagus to hold the $10 \mathrm{~mm}$ diameter stainless steel bars (Figure 17). One end of the bar was used to fasten the glued fragments and the other as a skeleton for pieces reconstructed in synthetic stone (Zohil, 2018). In areas holding the skeleton for reconstruction, horizontal $4 \mathrm{~mm}$ diameter stainless steel bars were weaved into the vertical lattice. This type of meshwork is used in synthetic stone reconstructions (in this case, mineral plaster) (Figure 18) to absorb tensile forces, as synthetic stone is more susceptible to these and might cracks easily without the mesh.

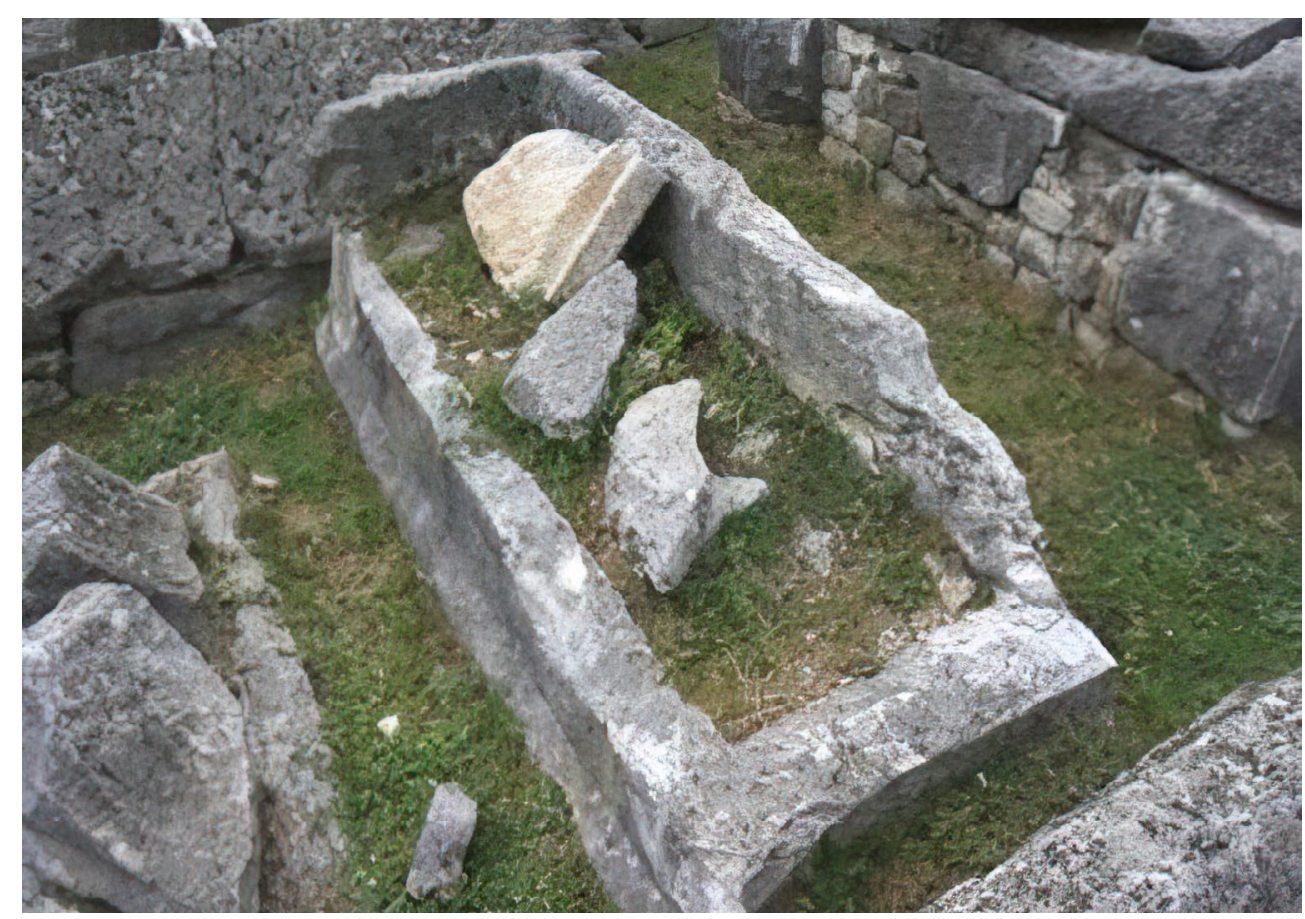

Figure 16. The initial condition of the sarcophagus of Quintia in Manastirine (photo by Siniša Bizjak, 2017).

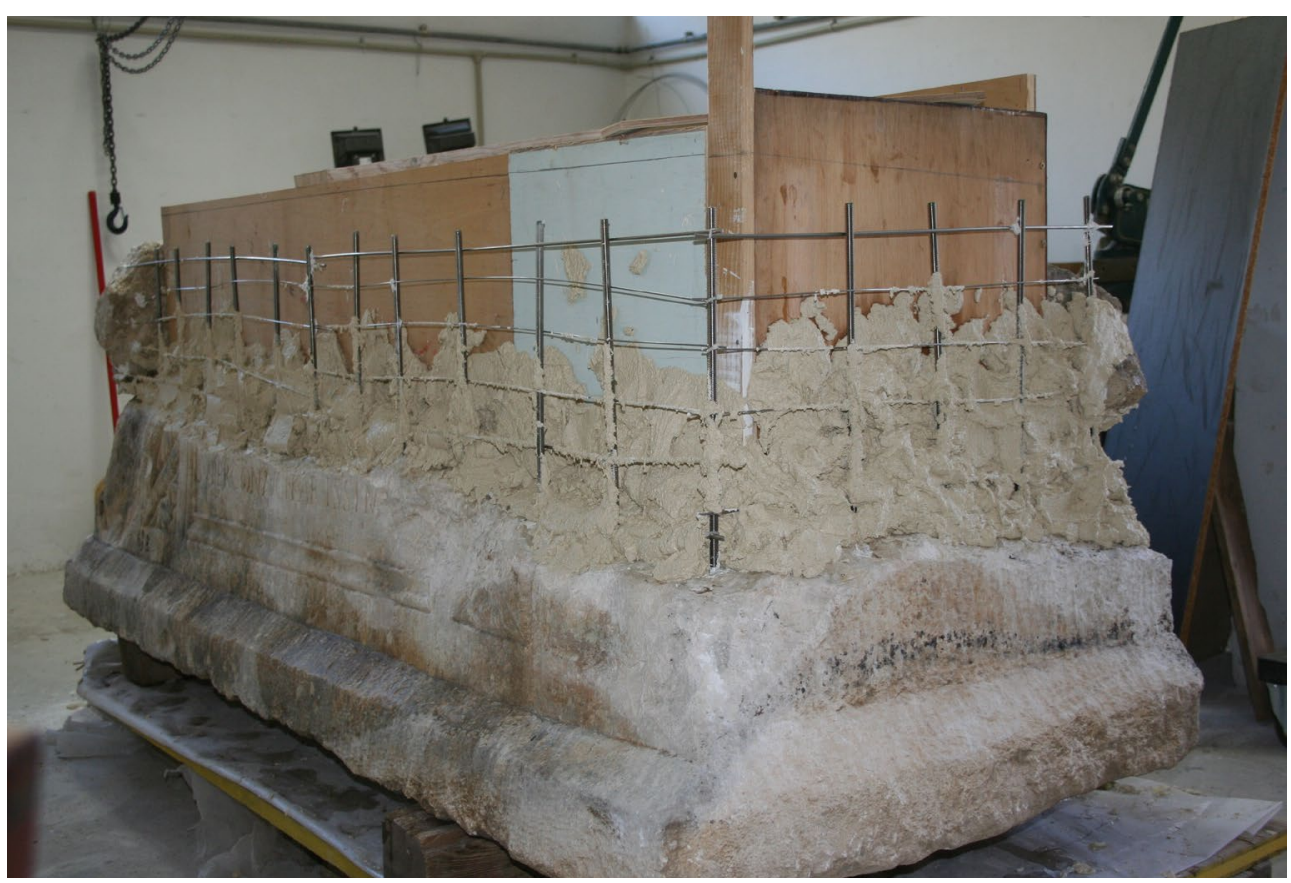

Figure 17. The installation of the reinforcement and application of reconstruction material (photo by Martin Zohil, 2017, reproduced with permission). 


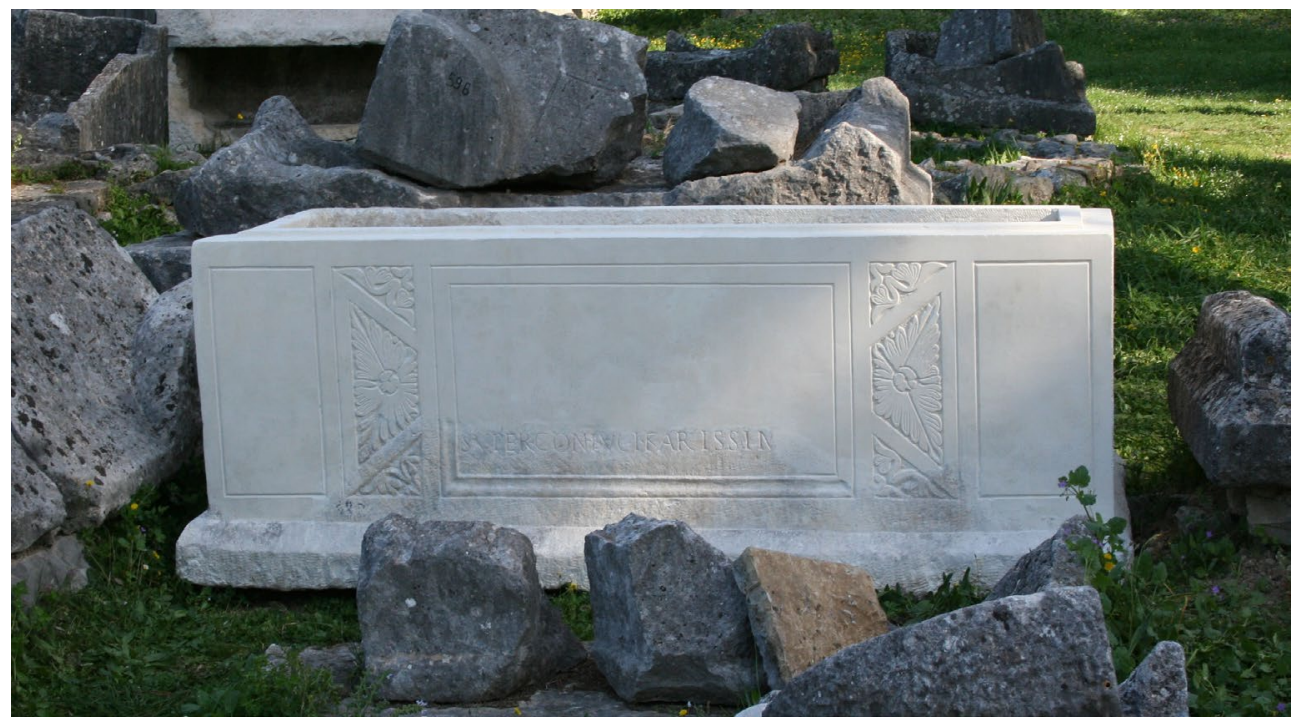

Figure 18. The sarcophagus after works (photo by Martin Zohil, 2019, reproduced with permission).

\section{Medieval portal at the Kaštel Kambelovac town gate, 2015}

The only preserved medieval entrance to the Town of Kaštela (Bego, 1911) was initially in such a poor condition that it required complete conservation and restoration (Bizjak \& Duvnjak, 2017). The whole portal had to be dismantled. We will not deal here with the restoration of the elements of the portal; instead, we will focus on the installation of a stainless-steel metal bar into the load-bearing lintel. The cracked portion on the right side of the lintel was worn-out and required replacing. The worn-out portion was reconstructed using natural stone and affixed to the lintel in the appropriate position. After bonding, a $30 \mathrm{~mm}$ wide and $2200 \mathrm{~mm}$ long opening was drilled through the centre of the lintel with an anti-vibration drill. A stainless-steel bar thread on both sides was embedded through the entire length of the lintel. Tightening nuts were placed on both ends of the embedded

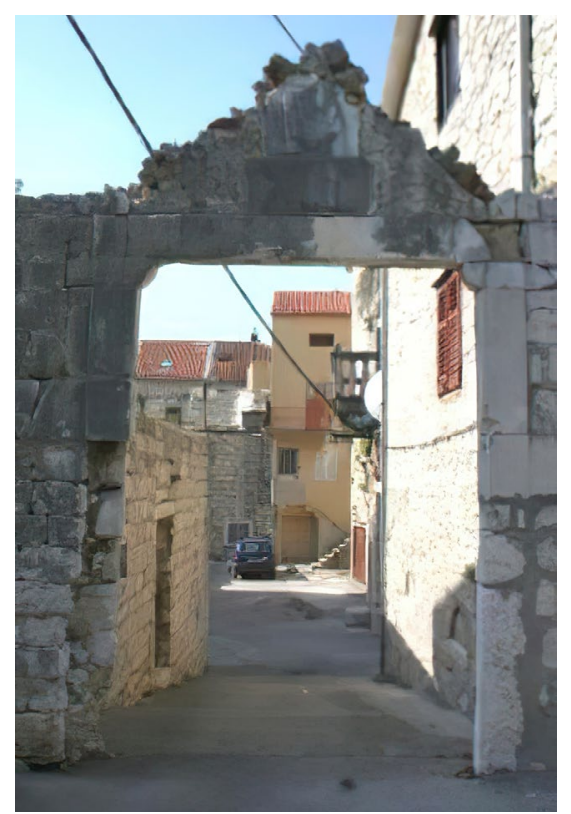

Figure 19. The initial condition of the portal with a visibly damaged lintel and missing parts in the left doorjamb (photo by Siniša Bizjak, 2015).

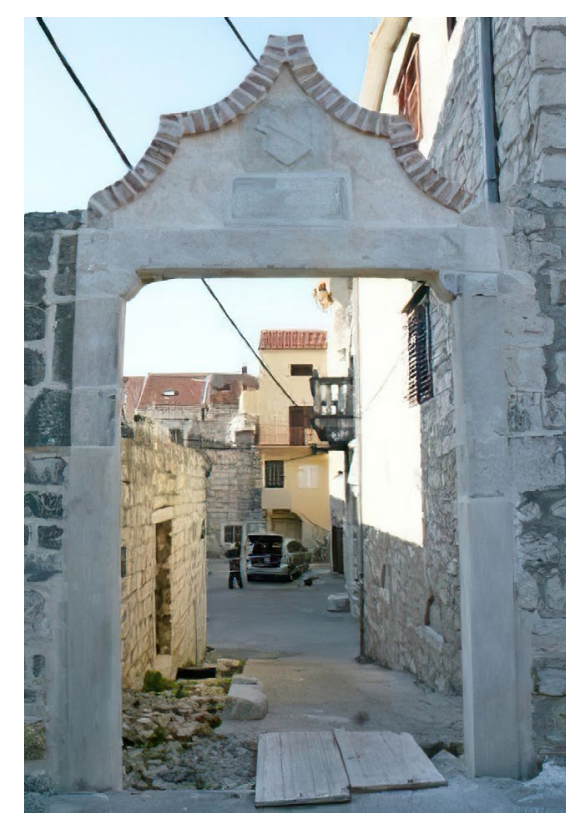

Figure 20. The portal after conservation and restoration works (photo by Siniša Bizjak, 2015). 
metal bar to secure the stone lintel in place. The bar was installed without adhesives to avoid heat damage to the stone. The reinforcement bar in the lintel absorbs a large portion of the load that used to act on the lintel itself and thus provides necessary structural stability to the portal (Figure 19, Figure 20, Figure 21).

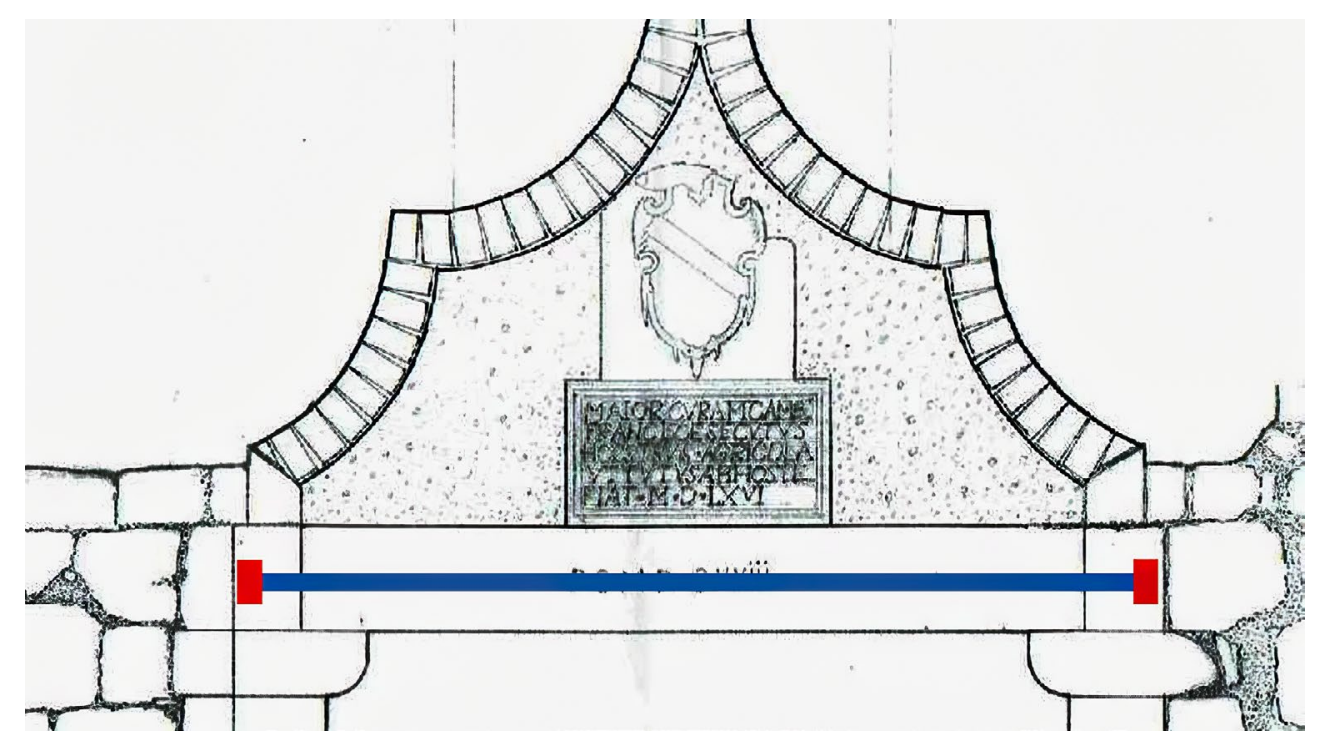

Figure 21. A schematic diagram of the reinforcement embedded in the portal lintel. The direction of the stainless-steel bar is shown in blue and the tightening nut in brown (drawing by Vinka Marinković, 2015, reproduced with permission).

\section{Baroque bell gable, Church of St. George the Martyr, Drvenik, 2016}

According to the markings engraved in the capital above the central column, the baroque bell gable was built in 1789 (Tomasović, 2007). Initially, the bell gable was statically unstable, as indicated by the several iron joints and clamps that were used to fixate it (Figure 22). Although installed in good faith, the number of iron joints in the bell gable seriously jeopardized the integrity of the monument so they needed to be removed and the entire bell tower dismantled. Following the removal of the iron members, an internal stainless-steel structure was constructed to secure the structural integrity of the bell gable. It is detachable and invisible to preserve the visual appearance of the monument. The reinforcement consists of $30 \mathrm{~mm}$ diameter pipes, which are anchored in the gable and extend vertically through the columns to the beam above the arches of the bell gable (Figure 23). In order to define verticals and drilling points, the bell gable was assembled in the workshop. The verticals were precisely defined with a laser. After the preparations in the workshop, the bell tower was transported to site in pieces. This was followed by the anchoring of the gable, using a $30 \mathrm{~mm}$ crown

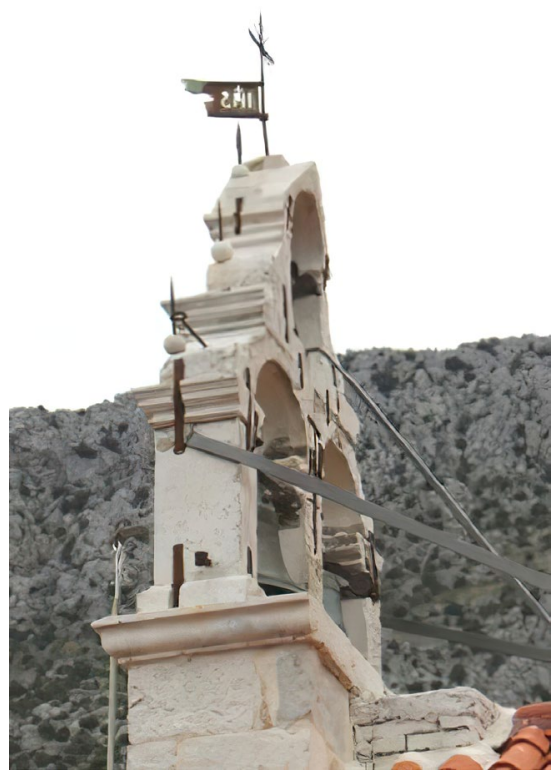

Figure 22. A detail of the initial condition of the bell gable with several poorly placed iron tie-beams (photo by Siniša Bizjak, 2016). 
drill bit at the depth of $40 \mathrm{~cm}$. Pipes were glued to the anchor holes and the structural elements of the bell tower were threaded onto them (Figure 24). Lime mortar was applied between the stone pieces to cushion the contact.

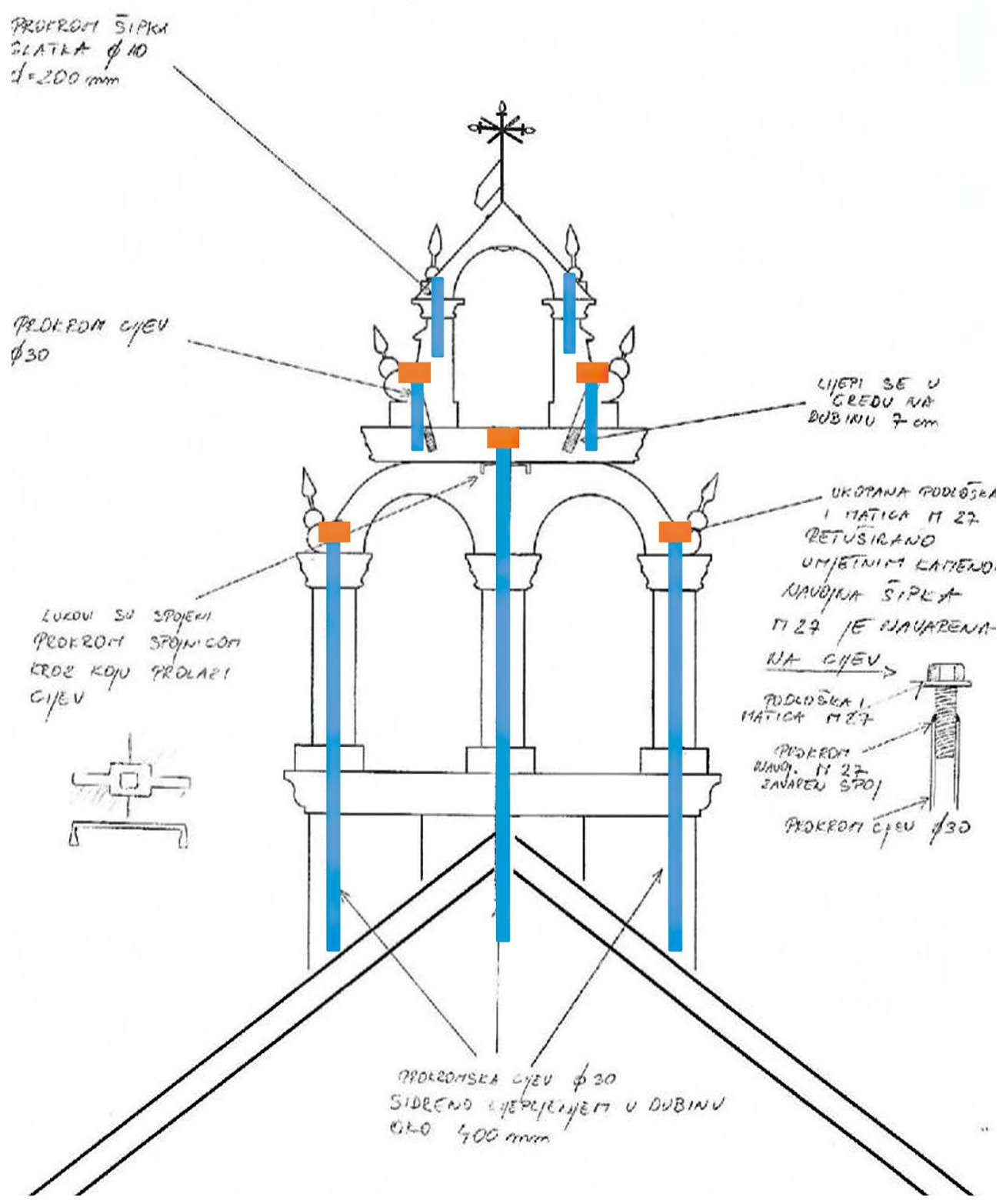

Figure 23. A schematic of a reversible steel structure embedded in the bell gable of the Church of St. George the Martyr. The direction of stainless-steel bars is shown in blue and tightening nuts in brown (drawing by Siniša Bizjak, 2016). 


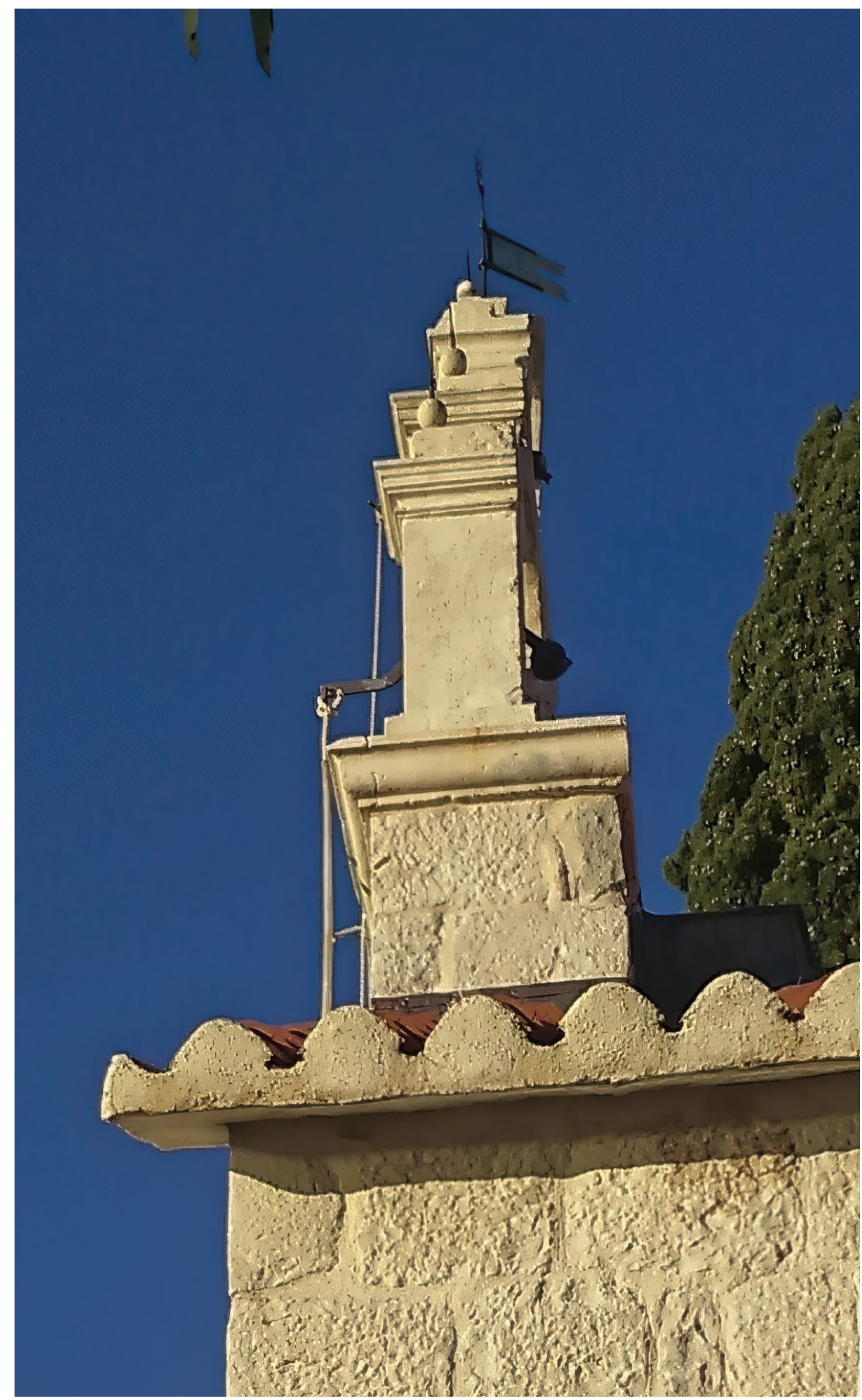

Figure 24. Church of St. George the Martyr in Drvenik, the same detail of the bell gable after the installation of stonework with no visible stainless-steel elements (photo by Siniša Bizjak, 2016). 


\section{Discussion}

The results presented in this paper provide an insight into the appropriate application of stainless steel in the conservation and restoration of stone cultural monuments. Today, stainless steel has a wide application; so wide, in fact, that one would be hard-pressed to find a trade or profession that does not make use of it. Carbon was also mentioned as a material with excellent properties suitable for installation into monuments, but carbon may only be used as a simple binder (for example, between two stone fragments) since it is difficult to process and does not weld (Donelli \& Malinar, 2015). Unlike carbon fibre profiles, stainless steel may be used in various structures due to its good machinability and weldability. The installation of stainless-steel elements may currently be the best and most efficient solution for ensuring sustainable stability, original appearance, and optimal positioning, as well as preventing further deterioration of monuments. By "preventing further deterioration”, we are referring to the key role of the installed structures, which is to absorb a large portion of the destructive forces acting on the already decaying stonework. We have selected examples of our work over the years to present some of the innovative solutions in conservation and restoration that are not the product of a trend or mere improvisation with new materials, but rather carefully crafted and measured interventions that strive towards the common goal of preserving our stone heritage for future generations.

Provenance: Submitted. This manuscript is based on the master's thesis by Jure Balić, deposited in the Dabar repository (https://urn.nsk.hr/urn:nbn:hr:175:010951).

Peer review: Externally peer reviewed.

Received: 30 September 2020 / Accepted: 19 April 2021 / Published online: 9 July 2021.

Acknowledgements: We would like to thank all our colleagues for the provided photo material, and especially for their patience as we implemented the described ideas and concepts into concrete works.

Funding: This research received no specific grant from any funding agency in public, commercial or not-for-profit sectors.

Authorship declaration: All persons who meet authorship criteria are listed as authors, and all authors certify that they have participated sufficiently in the work to take public responsibility for the content, including participation in the concept, design, analysis, writing, or revision of the manuscript.

Competing interests: The authors completed the ICMJE Unified Competing Interest form (available upon request from the corresponding author), and declare no conflicts of interest.

\section{ORCID}

Siniša Bizjak (D) https://orcid.org/0000-0001-8577-3341 


\section{References}

Adam, J. (2005). Roman Building: Materials and Techniques. London: Routledge, 95-105.

Awasthi, A., Gautam, A., \& Dheer, P. (2005). Linear Expansion Coefficient on Different Material Due to Temperature Effect. International Research Journal of Engineering and Technology (IRJET), 5, 4309-4311.

Barišić, M. (2010). Druga faza konzervatorsko restauratorskih radova na Peristilu. Kulturna baština, 36, 299-316.

Bego, F. (1911). Kaštel Kambelovac. Kaštela: Bijaći Cultural Heritage Preservation Society.

Bizjak, S., \& Duvnjak, I. (2017). Obnova kamenih vrata Kambelovca. Kaštelanski zbornik, 12, 28-38.

Bulić, F. (1904). Iscrizioni trovate nei dintorni del cemeterio antico cristiano di Manastirine. Bullettino di archeologia e storia dalmata, 27, 157-166.

Crnković, B., \& Šarić, L. (2003). Građenje prirodnim kamenom. Zagreb: Institut građevinara Hrvatske.

Čorić, D. (2017). Posebni metalni materijali - III Dio. Zagreb: Faculty of Mechanical Engineering and Naval Architecture.

Donelli, I., \& Malinar, H. (2015). Konzervacija i restauracija kamena. Split: University of Split.

Krstulović Opara, L. (2003). Izračun konstrukcije za sanaciju škropionica iz crkve sv. Eufemije. Split: Faculty of Electrical Engineering, Mechanical Engineering and Naval Architecture.

Lee, H. -Y. (2008). Investigation on the Use of Iron and Steel for Restoration Purposes during 19th and 20th Century. Barcelona: Technical University of Catalonia.

Marinković, V. (2014). Mramorne skulpture iz Narone - problem muzejske prezentacije. Portal, Godišnjak Hrvatskog restauratorskog zavoda, 5, 9-22.

Marković, V. (1996). Crkva Sv. Eufemije u Rovinju - između projekta i izgradnje. Prilozi povijesti umjetnosti u Dalmaciji, 36(1), 263-271.

Matijević, I. (2019). Životni suputnici rimskih vojnika na salonitanskim nadgrobnim natpisima iz doba principata. Radovi, 51 (2), 61-116.

Ončevska Todorovska, M. (2011). The Statue of Venus Pudica from Skupi. Folia archaeologica Balkanica II, 347-358.

Tomasović, M. (2007). Srednjovjekovni nadgrobni spomenici u makarskom primorju. Makarska: Makarska City Museum.

Zhang, X. G. (2011.). Galvanic Corrosion. In W. Revie (Ed.), Uhlig’s Corrosion Handbook, 3rd Edition. Ottawa: John Wiley \& Sons, Inc.

Zohil, M. (2018). Izvješće o konzervatorsko-restauratorskom zahvatu na kamenom sarkofagu Flavius Valens. Split: Arts Academy. 